\title{
Nowi „podporządkowani" w Wielkiej Brytanii. Środkowoeuropejski imigrant i jego filmowa personifikacja
}

\author{
Cristina Şandru
}

TEKSTY DRUGIE 2016, NR 3, S. 331-355

DOl: $10.18318 /$ td.2016.3.18

-ymbolika szczelin i rozłamów - ale również no- wych moźliwości - została ukształtowana na skutek przyspieszonego procesu wzrostu mobilności, przemieszczania się oraz migracji ludności na większą niż kiedykolwiek skalę̨. To z kolei - cytując słynne zdanie z powieści Szatańskie wersety Rushdiego ${ }^{2}$ - ukazuje imigrantów jako „istoty pozbawione ciągłości”, sekwencje liczb charakteryzujące się nieustannym przepływem, brakiem stabilności i wywoływaniem gwałtownych zmian w zakresie ekonomii czy technologii. W Europie

1 Zob. T. Neil The Figure of the Migrant, Stanford Univeristy Press, Stanford 2015 .

2 S. Rushdie Szatańskie wersety, Vintage, London 1998, s. 427. Zważywszy na to, że większość cytowanych w niniejszym artykule tytułów książek, opracowań bądź też filmów nie ma oficjalnego polskiego tłumaczenia, na potrzeby artykułu tłumacz pozwolił sobie na ich własne, amatorskie tłumaczenie. Zachowane zostały natomiast oficjalne polskie tłumaczenia publikacji, które ów przekład mają: Szatańskie wersety S. Rushdiego oraz Dwa domki na kółkach Mariny Lewyckiej [przyp. tłum].
Cristina Şandru - $d r_{i}$

redaktor naczelna The Literary Encyclopedia.

Współredagowała numer specjalny Journal of Postcolonial Writing (2012) poświęcony zagadnieniom postkomunizmu i postkolonializmu oraz monografię Rerouting the PostcoIonial: New Directions for the New Millenium (2009). Ostatnio opublikowała: Worids Apart? A Postcolonial Reading of post-1945 East-Central European Culture (2012). 
po zimnej wojnie wzrost mobilności sukcesywnie przekładał się na kolejne fale 'nomadyzmu', spowodowane rozmaitymi napięciami ekonomicznymi oraz kuszącą wizją nieosiągalnego dotychczas Zachodu. Niewielka fala $\mathrm{z} 1990$ roku, kiedy to nadzieje związane z nagłym polepszeniem bytu wciąż były żywe u mieszkańców Europy Środkowej, przerodziła się w poakcesyjny przypływ i nie lada inwazję (lub, jeśli przyjąć perspektywę krajów emigracyjnych, „drenaż mózgów” tudziez ściąganie specjalistów z krajów rozwijających się do krajów rozwiniętych). Migracja ludności z krajów środkowoeuropejskich na Zachód wciąż stanowi realną rzeczywistość demograficzną w Europie. W Wielkiej Brytanii, podobnie jak i w innych krajach przyjmujących nowych imigrantów, ich obecność wywiera znaczący wpływ na aktualnie debaty dotyczące integracji imigrantów z natywnymi mieszkańcami, praw człowieka, kwestii obywatelskich, zróżnicowania kulturowego czy tożsamości narodowej.

W niniejszym artykule biorę pod lupę współczesne produkcje kinowe oraz telewizyjne, które zajmują się „problemem” nowo-europejskiej imigracji w Wielkiej Brytanii: krótkie ujęcia dokumentalne w reportażach (np. The Poles Are Coming ${ }^{3}$ [Polacy nadchodzą] z 2008 roku, The Great Big Romanian Invasion ${ }^{4}$ [Wielka rumuńska inwazja] z 2014 roku czy choćby trzyodcinkowy serial The Romanians Are Coming 5 [Rumuni nadchodza] z 2015 roku, proza (Outlanders ${ }^{6}$ [Autsajderzy] Dominica Lees z 2007 roku czy połączenie filmu dokumentalnego i dramatu (It's a Free World? [Wolny świat] Kena Loacha z 2007 roku.

Historie przedstawione w tych filmach koncentrują się wokół - by zacytować krótki komentarz Karela z filmu Wolny świat - tzw. „trzeciego świata Londynu". Imigranci są tutaj przedstawieni w kategoriach towaru eksploatowanego przez system globalnego kapitalizmu opartego na taniej sile roboczej,

3 The Poles Are Coming, written and presented by T. Samuels. BBC2, Television, 11 March 2008.

4 The Great Big Romanian Invasion, written and presented by T. Samuels, dir. A. Fellows., BBC1, Television special documentary, 17 July 2014.

5 The Romanians Are Coming, Ddir. and prod. I. Bluemel, narrated by A. Fechete Petru, Keo Films and Channel 4, Television documentary series, February-March 2015.

6 Outlanders, dir. D. Lees, Sterling Pictures/Storm Entertainment, film, 2008.

7 It's a Free World!, dir. K. Loach. Filmcoopi Zürich, BIM Distribuzione, EMC Produktion, DVD, 2007.

8 "A ci wszyscy ludzie? Skąd oni się tu wzięli?" "Zewsząd. Z Brazylii, Afganistanu, Polski, Ukrainy, Iraku. Obiecano im pracę i nawciskano kitu. Istny Trzeci Świat w tym Londynie" $\left(0.30^{\prime} .20^{\prime \prime}\right)$. 
trzymanego jednak w ryzach przez politykę państwa opiekuńczego. Rzecz jasna kraje, z których wyżej wspomniani imigranci pochodzą (głównie Polska i Rumunia, w tym wypadku, bo głównie pochodzą z Bangladeszu, Indii, Chin itd.), ukazane są jako trawione biedą dzielnice nędzy (albo - mówiąc delikatnie - przytłaczająco ponure miejsca), zawieszone niepewnie między zgliszczami pozostawionymi przez postkomunistyczną i postindustrialną rzeczywistość, stanowiące coś na kształt miejskich slumsów. Choć miejscami odwoływać się będę do wszystkich wspominanych wyżej tytułów, skupię się w dużej mierze na transmitowanych w Channel 4 obrazach Rumuni nadchodza oraz Wolny świat.

Moim głównym celem jest dokładne przyjrzenie się zaprezentowanej przez filmowców narracji, która - bez wyjątku - prezentuje „nowych podporządkowanych" postrzeganych z empatią, lecz nie bez protekcjonalnego tonu i krzywdzących uproszczeń. Jeśli przyjąć, że migracja na skalę globalną to moneta o dwóch awersach, to przypominając słowa Zygmunta Baumana ${ }^{10}$ - filmy te ukazują migracje w mniejszym zakresie (w szerszym kontekście ukazującym podróże w celach akademickich, biznesowych, zawodowych czy urlopowych widzianych przez pryzmat tzw. turystyki), zachowując jednocześnie wyraźną dozę „włóczęgostwa” (szczególnie w formie nieudokumentowanej pracy - zobacz: Bauman : 1998, rozdział 4). Płynne spektrum, z początku nieszczelne i przepuszczające wodę, przybrało jednak z czasem postać stałej geometrycznej, z wnętrza której podporządkowani nie mogą mówić, ponieważ nikt nie słyszy ich głosu zza pleców pozbawionych skrupułów handlarzy niewolników, odbierających ich o świcie i przewożących w ciasnych przyczepach do nic nieznaczącej roboty, na której opiera się cały system kapitalistyczny, ale która w większości przypadków wydaje się pomijana. Omawiane filmy pokazują wyraźnie, że imigrant to nie tylko ucieleśnienie prominentnej figury politycznej naszych czasów, ale także kwintesencja rozproszonej stolicy, w której prym wiodą różnego rodzaju prace „3D” (oryg. „dirty, dangerous

9 Z ang. "subaltern" - termin niezwykle trudny do przełożenia na język polski, wprowadzony przez przez G.Ch. Spivak (esej opublikowany w zbiorze Marxism and the Interpretation of Culture pod redakcją Cary'ego Nelsona i Lawrence'a Grossberga z roku 1988); najczęściej tłumaczony jako „podporządkowany/podporządkowana" - jest obecnie jednym z kluczowych pojęć w analizie społecznych relacji władzy; esejzostał przetłumaczony na język polski, gdzie nadano mu tytuł Czy podporzqdkowani inni moga przemówić? - ukazał się w roku 2001 w kwartalniku "Krytyka Polityczna" [przyp. tłum.]

10 Z. Bauman Globalization: The Human Consequences, Columbia University Press, New York 1998. 
and dull"11) (Favell'12) - bądź teź, cytując Alexa (jednego z bohaterów Rumuni nadchodza), "gówniane zajęcia"13 , do których angażuje się głównie ludzi do pracy tymczasowej, a nie stałej, a ich przejściowy status oraz brak adaptacji kulturowej do kraju docelowego czyni z nich ludzi pozbawionych głosu nawet bardziej niż w przypadku typowej imigracji postkolonialnej.

Jak próbowałam dowieść już wcześniej"14, imigranci środkowoeuropejscy wciąż są rozproszeni, brak im stabilizacji oraz chęci integrowania się - choć pewnie są i tacy, którzy indywidualnie są w stanie się zasymilować (np. odnoszący sukcesy wykwalifikowani specjaliści). Zjawisko to nie odnosi się do ukształtowanych w czasach postkolonialnych większych grup imigranckich w zachodnich metropoliach, które tworzyły własne mikrospołeczności, a ich kultura, religia, obyczaje i styl życia na stałe wpisały się w kulturę dominującą. Jednym z powodów tego stanu rzeczy jest to, że imigracja i integracja zazwyczaj nie idą ze sobą w parze, a tymczasowy lub krótkotrwały pobyt zaczyna powoli wypierać naturalizację. Tak z pewnością dzieje się w przypadku większości imigrantów z Europy Środkowej, których traktuje się na ogół jak ludzi drugiej kategorii ze względu na ich niechęć do osiadania na stałe w nowym miejscu. Ich życie nacechowane jest ciągłym przemieszczaniem się oraz brakiem przynależności do jednego miejsca - co z kolei prowadzi do powrotu do krajów, które przecieź sami wcześniej opuścili. Stąd też obecność "Polaczków" pojawiających się coraz tłumniej w takich miejscowościach jak Peterborough wywołuje ostrą reakcję starszych mieszkańców miasta: 84-letnia Marge w reportażu Tima Samuelsa Polacy nadchodzą mówi np.: „Naprawdę czuję się jak ktoś obcy we własnym kraju"15. Okoliczności często zmuszają takich

11 „Dirty, dangerous and dull” - z ang. brudne, niebezpieczne i nudne (przyp. tłumacza).

12 A. Favell The New Face of East-West Migration in Europe " Journal of Ethnic and Migration Studies" $2008(34: 5)$, s. 704.

13 "W pewnym sensie zabieramy ludziom robotę... ale tylko taką gównianą - zamiatanie ulic mycie aut, cośw tym stylu... jakaś tam robota przy azbeście" (odcinek 1, 0.14'.54").

14 Zob.: foined at the Hip? About Post-Communism in a (Revised) Postcolonial Mode, w: Postcolonial Europe: Essays on Post-Communist Literatures and Cultures, Brill, Amsterdam 2015.

15 Ta kwestia sama w sobie, a także jej socjologiczne, ekonomiczne czy polityczne implikacje zasługują na bardziej szczegółową analizę. Nowa fala środkowowschodnich imigrantów jest rozproszona po metropoliach, cozmusza imigrantów do dzielenia najbliższej przestrzeni życiowej ze "starszymi" społecznościami imigranckimi, którez kolei zastąpiły białe klasy robotnicze. Powoduje to eskalację napięć między różnymi grupami. Z jednej strony wzmaga irytację, niepokój i najgorsze przeczucia u tych rodowitych Brytyjczyków, którzy- gdy wypowiadają się na temat imigrantów, nierzadko używają niewybrednego słownictwa: „Ten kraj został całkowicie 
środkowoeuropejskich imigrantów, posługujących się łamaną angielszczyzną i niezbyt wykwalifikowanych, do podejmowania mniej lub bardziej „gównianej roboty" ${ }^{16}$, zagarniania przestrzeni dla siebie i sporadycznego stykania się w pracy ze światem mieszkańców państwa goszczącego. Poza pracą żyją we własnym gronie, zamknięci w swojej europejskości (ile narodów, tyle wersji - ponieważ w większości przypadków domy zamieszkiwane są przez imigrantów pochodzących z tego samego kraju).

To oczywiście tylko jedna strona medalu, bardzo często podnoszona w mediach, istotna w procesie tworzenia ujednoliconego dyskursu publicznego, w którym od wielu lat przewija się motyw strachu przed „kontaminacją” czy „okupacją”. Jednak to, co tutaj mniej widoczne, to zgoła odmienny trend panujący wśród środkowoeuropejskich imigrantów, a mianowicie słaby związek z własnym krajem, spowodowany pragnieniem odrzucenia przeszłości. Dla wykwalifikowanych środkowoeuropejskich imigrantów (którzy podjęli decyzję o pracy oraz osiedleniu się w Wielkiej Brytanii z innych powodów niż przystąpienie ich krajów do Unii Europejskiej), klasa społeczna oraz edukacja często są istotniejsze niż przynaleźność do określonej grupy etnicznej. Taki imigrant nie jest ani pozbawiony możliwości decydowania o sobie, ani też nie jest postrzegany jako ktoś gorszy ${ }^{17}$ - on bądź ona właśnie zasilili szeregi drugiego i trzeciego pokolenia odnoszących sukcesy zawodowe hinduskich czy pakistańskich lekarzy, informatyków bądź analityków finansowych, idealnie wpasowując się w zaproponowaną przez Étienne Balibar ${ }^{18}$ definicję „inności mieszczącej się w kategoriach pełnoprawnego obywatela" - dającego

zalany bagnem” (Polacy nadchodza); „najechali nas i zalali” (Wielka rumuńska inwazja). Z drugiej zaś strony prezentuje, w jaki sposób stopniowo napływający do kraju imigranci zdążyli się zaaklimatyzować i zasymilować na tyle, że powstające, jak grzyby po deszczu, indyjskie czy chińskie sklepy nikogo już nie dziwią (Wielka rumuńska inwazia). Co ciekawe, ogromna liczba wschodnioeuropejskich sklepów spożywczych nadal traktowana jest podejrzliwie, nawet $z$ tak błahego powodu, jak wydrukowane w nieznanym języku informacje na opakowaniach produktów.

Warto przyjrzeć się, jak sam reżyser - Tim Samuels - podnosi tę kwestię w obrazie Wielka rumuńska inwazja, kiedy to bada przeszłość członków własnej rodziny i odkrywa, że zarówno w ówczesnej prasie, jak i w ówczesnym dyskursie politycznym reakcje na imigrantów w późnych latach 9o. w Wielkiej Brytanii praktycznie wiele się nie różniły od komentarzy dotyczących "fali" żydowskich imigrantów politycznych bądź też uchodźców politycznych z Rumuni iz innych krajów Europy Wschodniej.

17 Jak dowodzi w swoich badaniach Tom Neil, każdy ruch migracyjny wiąże się - w mniejszym lub większym stopniu - z wykluczeniem społecznym. 
się „oswoić”, zdolnego do asymilacji oraz takiego, którego moźna utrzymać w ryzach. To wyjaśniałoby poczucie braku przynależności wśród rodaków wykonujących najgorsze prace w hotelach, na polach czy na budowach w obrębie Zjednoczonego Królestwa. W przeciwieństwie do tych drugich, grupa najbardziej wykształconych i piastujących wysokie stanowiska imigrantów właściwie nie istnieje w dyskursie publicznym (z czego zresztą sami zainteresowani raczej się cieszą). Specjalnie się nie wyróżniają i na ogół potrafią wpasować się w akceptowaną przez innych kosmopolityczną elitę wielkich miast. Ten typ imigrantów jest bardzo rzadko pokazywany w filmach dokumentalnych. Prowadzi to do swoistego absurdu: ci, którym się udało i którzy są znacznie bardziej uprzywilejowani, ekonomicznie i społecznie - są równocześnie najmniej słyszalni.

Efektem tego dysfunkcyjnego charakteru migracji z krajów Europy Środkowo-Wschodniej okazuje się to, że tak rozproszone grupy z dawnych krajów komunistycznych nie przekształciły się jeszcze w charakterystyczne społeczności kulturowe - w przeciwieństwie do wielu mniejszości (rasowych, seksualnych, związanych z gender), brakuje im funkcji stricte politycznej w debacie publicznej i świadomości typowej dla ludzi Zachodu - chyba że sprawa dotyczy szkalowania bądź szukania kozła ofiarnego. Warto zauważyć, że większość z nich nie ma nawet statusu obywatela w krajach, które zamieszkują. Ich obecność jest nieustannie podkreślana w rozmaitych przepychankach politycznych; z drugiej zaś jawią się jako niewielki odsetek kosmopolitycznej i wielokulturowej miejskiej masy. W związku z tym obydwie grupy mogą być zdefiniowane w tych samych kategoriach, braku głosu” - pierwsza z uwagi na to, że ledwo „mówi” (bądź też takie wrażenie sprawia w kontakcie z natywnymi mieszkańcami) czy też dlatego, że jej głos nie jest wystarczająco silny; druga - mimo że jej członkowie to osoby zdolne do indywidualnej artykulacji i w znakomitej większości płynnie posługujące się językiem angielskim - ze względu na akcent zdradzający ich „obcość”.

W niniejszym artykule przyjrzę się tytułowemu pytaniu postawionemu w publikacji Rostek i Uffelmann z 2010 roku ${ }^{19}$ : „Czy środkowoeuropejski imigrant jest w stanie mówić"? Jeśli chodzi o strategie reprezentacyjne, można zidentyfikować dwa zasadnicze aspekty medium filmowego, dzięki którym

19 J. Rostek, D. Uffelmann Can the Polish Migrant Speak? The Representation of 'Subaltern' Polish Migrants in Film, Literature and Music from Britain and Poland, w: Facing the East in the West: Images of Eastern Europe in British Literature, Film and Culture, eds B. Kor te, E.U. Pirker, S. Helff, Rodopi, Amsterdam-New York 2010, s. 311-334. 
takie luki powstają: po pierwsze - budowanie wizerunku samego w sobie (włączając w to perspektywę obiektywu kamery, dominujący rodzaj ogniskowej, wybór tła, zbliżenia, przesunięcia itd.); po drugie - kwestia "głosu", widziana zarówno z perspektywy osób wypowiadających się, słuchających czy tych, których głos jest słyszalny, jak i w czysto filozoficznym i teoretycznym ujęciu tego zagadnienia, leżącego u podstaw wszystkich nacechowanych politycznie historii, stanowiącego przy tym tzw. ciężar gatunkowy.

W centrum zainteresowania omawianych wyżej produkcji znajduje się postać tzw. imigranta ekonomicznego - typowy polski, ukraiński, rumuński, mołdawski, czeski zbieracz owoców, budowlaniec, pomoc domowa lub ich odpowiedniki, typowi „mobilfon meni” - jak w uproszczeniu nazywani są w ukraińsko-brytyjskiej powieści Mariny Lewyckiej Dwa domki na kótkach ${ }^{20}$. To pojęcie mówi wszystko o nowobogackich rekinach finansjery typowych dla postkomunistycznego dzikiego kapitalizmu. Uprawiają oni handel ludźmi, szastają ich nadziejami, marzeniami i ambicjami, zmuszając do marnej pracy na czarno, na granicy prawa. W obrazie Autsajderzy Dominica Lees jako przykład takiego działania podaje się status robotników pracujących na budowach głównie we wschodniej części Londynu, gdzie praca staje się współczesną formą niewolnictwa - praktyka ta jest łudząco podobna do tej stosowanej na ogromną skalę przez bogate kraje arabskie, w których zabieranie Filipińczykom czy Pakistańczykom dowodów tożsamości jest na porządku dziennym (w filmie Jan stosuje podobne praktyki w stosunku do nowej grupy przyjezdnych). Metaforyczny, sugestywny tytuł pozwala umiejscowić tych ludzi w obcym miejscu, gdzie ciemne interesy czy niepewne zakwaterowanie są na porządku dziennym. Tutaj nie tylko zabiera im się paszporty - przez co imigranci tracą nie tylko toźsamość narodową, ale także kontrolę nad własnym życiem. Poza tym są traktowani jak bydło i gdy - przykładowo - któryś z nich, pracując na budowie, ześlizgnie się z lichego rusztowania, jego ciało zostaje szybko zakopane i znika z powierzchni ziemi, żeby jego pracodawcy mogli uniknąć skandalu. Podobne sytuacje są istotne z punktu widzenia bieżącej fali imigrantów - uchodźcy polityczni i osoby poszukujące azylu (głównie Ukraińcy i Rosjanie) ryzykują życie, przepływając wzburzone wody Morza Śródziemnego na przepełnionych pontonach po to, by dostać się do Wielkiej Brytanii i ugrzęznąć w świecie szemranych interesów.

W interpretacji takich obrazów odwołanie do marksistowskiej utopii nasuwa się automatycznie - staje się jasne, że jedyna forma wolności, jaką 
mogą cieszyć się imigranci, daje rozmaitym cwaniakom i hochsztaplerom zielone światło do wyzysku na masową skalę. Taki stan rzeczy stanowi lżejszą formę imperializmu, która niegdyś pozwalała rozwijać się kapitalistycznym państwom Pierwszego Świata kosztem państw Trzeciego Świata - dziś są to postkomunistyczne społeczności, określane mianem Drugiego Świata. Zgodnie z tym, co zauważa Favell ${ }^{21}$, wielu imigrantów godzi się na takie urągające godności ludzkiej warunki pracy i życia tylko po to, by wypełnić tę najgorszą niszę na rynku pracy. Zjawisko to tłumaczy się koniecznością spłacenia długu zaciągniętego przez rodzinę imigranta za przewiezienie go do danego kraju. Niemniej jednak populistyczne i ksenofobiczne reakcje na obecność imigrantów - będące skutkiem zauważalnej konkurencji na rynku pracy - powodują, że przyjezdni często usuwają się w cień jako niewidzialna, acz sprawnie funkcjonująca „drugorzędna” gałąź ekonomiczna. Wykonują przy tym prace, których nie chcą podejmować się rodowici mieszkańcy Wielkiej Brytanii (jak np. siedzenie w kasie w sieciówce, sprzątanie, prasowanie w prywatnych domach czy choćby zbieranie dyni piżmowej na polach wschodniej Anglii - „fucha”, której nie podjąłby się nawet Brytyjczyk na zasiłku; wystarczy popatrzeć na ich twarze wyrażające coś na granicy niesmaku i konsternacji, gdy Tim Samuels mówi im o niektórych pracach wręcz ochoczo wykonywanych przez Polaków). Nawet ojciec Angie (z filmu Kena Loacha), który martwi się o przyszłość swojego wnuka, zmuszonego zapewne do walki o miejsce pracy z tymi wszystkimi „Kosowianami i Rumunami”, jest wzburzony słowami córki, która nie przejawia żadnej empatii wobec imigrantów: „Dawać im szansę? A co z ich własnymi krajami? Nauczyciele, pielęgniarki, lekarze. Przyjeżdżają tutaj i pracują w knajpach za głodowe pensje. Co w tym dobrego?" (0.46'.20"). W tym samym tonie Alex - rumuński narrator serii Rumuni nadchodza emitowanej w brytyjskim kanale Channel 4 - szuka usprawiedliwienia dla przyjmowania przez imigrantów prac uznawanych za najmniej prestiżowe. Według niego wynika to z biedy, od której nie można uciec: „[...] Anglia wypełniona jest po brzegi rumuńskimi nauczycielami czy inżynierami zarabiającymi tutaj więcej przy zbiorze malin, niż gdyby pracowali w zawodzie w ojczystym kraju" (19'56").

Choć z tego typu tekstów bije pryncypialność, nie lada to zadanie dla lewicowego bojownika-intelektualisty mówiącego w imieniu wykluczonych naturalnie z pomocą tych, którzy wydają się wiarygodnymi mówcami: emeryt należący do brytyjskiej klasy pracowniczej, który rozumie potrzeby i niepokój

21 A. Favell The New Face of East-West Migration in Europe, s. 712. 
emigrantów, bądź też spychani na margines i wykluczani rumuńscy Romowie. Oczywiście według obecnych statystyk nie znajdziemy wielu lekarzy czy pielęgniarek wykonujących kiepsko płatne, "gówniane zajęcia” - zamiast tego zapełniają sporą ilość etatów w obleganym sektorze $\mathrm{NHS}^{22}$, nad którym z kolei - na co zwraca uwagę wielu komentatorów politycznych - wisi widmo natychmiastowego upadku w sytuacji braku napływu pracowników medycznych z zagranicy. Z kolei inżynierowie - o ile są dobrzy w swym fachu - mają większe szanse na znalezienie pracy w międzynarodowych korporacjach niż zbieranie malin na brytyjskich polach.

Powyższe stwierdzenia stanowią główną linię krytyki, która pojawia się w odniesieniu do serialu dokumentalnego Rumuni nadchodza. Wyemitowany na krótko przez majowymi wyborami parlamentarnymi na Wyspach Brytyjskich, film wywołał wiele kontrowersji i odebrany został przez wiele osób (a w szczególności przez rumuńską społeczność zamieszkującą Wielką Brytanię) jako obraz propagandowo korzystny, nakręcających już wcześniej populistyczne lęki i ksenofobiczne tendencje związane z migracją ludności z Europy Wschodniej w ramach rozszerzenia Unii Europejskiej. Wistocie film balansuje na cienkiej granicy między przed stawianiem wstrząsających ludzkich historii a wycinaniem tych bardziej „wygodnych” fragmentów i edytowaniem ich $w$ taki sposób, żeby pokazać tylko jeden aspekt rumuńskiej imigracji w Wielkiej Brytanii. Kluczowe pytania, które nasuwają się w związku z tym filmem mają moim zdaniem wiele wspólnego z dwoma głównymi zagadnieniami, które są podstawą tego typu filmów: docelowy odbiorca (target) oraz perspektywa - zarówno narracyjna, jak i wizualna. Rzecz jasna, olbrzymia grupa obywateli Wysp Brytyjskich, którzy regularnie zasiadają przed telewizorami około 9.00 wieczorem, miała szansę obejrzeć film i - w zaleźności oczywiście od przynaleźności do określonej klasy społecznej, wykształcenia, rasy, uwarunkowania geograficznego oraz wielu innych czynników socjologicznych (włączając w to ewentualny wcześniejszy kontakt z osobami pochodzenia rumuńskiego) - mogła wyrobić sobie różne opinie na jego temat. Jednocześnie wielu Rumunów mieszkających na Wyspach Brytyjskich z pewnością film widziało. Wielu z nich towarzyszyły jak najgorsze przeczucia odnośnie do przedstawionych w filmie historii (przeczucia, które w większości przypadków dało się uzasadnić na podstawie jego treści). Nawet najbardziej pobieżna analiza stron internetowych - miejsca żarliwych dyskusji na temat

22 w Wielkiej Brytanii, finansowanych ze środków publicznych. 
dopiero co obejrzanego filmu - pokazuje bitwę na argumenty między tymi, którzy krytycznie podchodzą do wszelkich prób ukazania rumuńskich imigrantów przez pryzmat stereotypów, oraz tymi (a tych jest znacznie mniej), którzy byli w stanie wyłapać pełne ironii niuanse dostrzegalne między wierszami i wypływające spod ramy wizualnej i narracyjnej. Pod wieloma względami opisana powyżej przepaść wynikająca z różnicy zdań wskazuje nie tylko na schizofreniczne samopostrzeganie narodu rumuńskiego ${ }^{23}$ (jak już wcześniej wspominałam - dotyczące także mniejszych środkowoeuropejskich narodowości), ale także na dwuznaczność danego środka przekazu.

Począwszy od tytułu, przedimek określony „the" jest tutaj główną kością niezgody: jako wyznacznik zarówno jednolitości, jak i pewnej całości (w tym sensie „the” oznacza ogół Rumunów, którzy przyjeżdżają do Wielkiej Brytanii - różne rodzaje ludzi zobrazowanych w filmie, np. biedni lub będący na skraju ubóstwa, cyganie czy wręcz „szumowiny”). Tytuł jest też bardzo ironiczny, choć tutaj i tak znajdziemy mniejszą dawkę sarkazmu niż w utrzymanym w szyderczym tonie obrazie wyprodukowanym przez BBC - Wielka Rumuńska inwazja Tima Samuelsa ${ }^{24}$. „A co ze specjalistami do spraw oprogramowania, programistami, analitykami finansowymi, specjalistami do spraw telekomunikacji czy lekarzami, którzy napędzają brytyjską gospodarkę, bazującą na ich umiejętnościach, wdrażanych przez nich innowacjach czy po prostu ciężkiej pracy? Dlaczego zabrakło ich w niniejszych «dokumentach»?" - to najczęściej powtarzające się pytanie na niezliczonych blogach i forach publicznych od razu po emisji filmu. „Dlaczego niejaki Alex Fechete - Cygan - jest narratorem w obrazie dotyczącym przyjazdu Rumunów?" - a zatem należałoby

$23 Z$ jednej strony są bojowo nastawieni do Cyganów i to negatywne nastawienie jest widoczne także w innych filmach, gdzie bohaterami są rumuńscy imigranci (jak np. Wielka rumuńska inwazja Tima Samuelsa); ciągle wietrzą zorganizowany przeciwko nim powszechny cygański spisek; z drugiej strony wstydzą się swoich korzeni, brudu i totalnie nieucywilizowanej natury swej ojczyzny.

24 Tutaj da się zaobserwować osobliwy kontrast między "inwazją" sugerowaną w tytule (o której nieustannie trąbili zarówno politycy, jak i wszelakiej maści eksperci) oraz stanem faktycznym, tj. 1 stycznia 2007 roku - w dniu wstąpienia do Unii Europejskiej nowych państw członkowskich, m.in. Rumunii i Bułgarii. Co się okazało, tego dnia przybył tylko jeden obywatel rumuński - Victor Spirescu, hodowca trzody chlewnej - który na początku lekko oszołomiony i zakłopotany, od razu znalazł się w centrum ogromnego zainteresowania mediów: obecność kamer i dziennikarzy obecnych na miejscu, by udokumentować tę "wielką inwazjię", podziałała na niego przy tłaczająco. Mimo to na chwilę stał się telewizyjnym celebrytą; niestety wkrótce stał się obiektem ogólnej debaty publicznej i nienawiści - podzielając tym samym los zmanierowanych pseudogwiazdek. 
stawić czoła typowo postkolonialnej kwestii „ciężaru gatunkowego” zaprezentowanego materiału. O kim ten film mówi - ale także, co najwaźniejsze, w czyim imieniu to robi? W przypadku filmów, których zamiarem jest udokumentowanie danego zjawiska - te pytania wydają się podwójnie istotne: w przeciwieństwie do produkcji stricte „artystycznych" celem dokumentatora jest umożliwienie bohaterom filmu zabrania głosu bezpośrednio, wręcz stworzenie im warunków do swobodnego i szczerego wypowiedzenia się a takiej moźliwości nie dają im media publiczne. Oczywiście trzeba wziąć pod uwagę ograniczenia możliwości czasowych i edycyjnych; wypowiedzi wybranych bohaterów już wcześniej przeszły dokładną selekcję, zostały odpowiednio przetłumaczone bądź też całkowicie wyeliminowane z ostatecznej wersji filmu. Co więcej, w przypadku filmu, który analizuję, kwestią szczególnie drażliwą wydaje się pytanie o to, którzy dokładnie „imigranci” są na tyle reprezentatywni, żeby wystąpić w dokumencie. Natomiast wybór postaci przez filmowców może być odczytany raczej jako wskaźnik oczekiwań odbiorców niż uchwycenie rzeczywistości w jej prawdziwej postaci. To tutaj tkwi główna przyczyna powszechnego oburzenia, jakie film wywołał, szczególnie wśród sporej części społeczności rumuńskiej, zarówno na Wyspach Brytyjskich, jak i w samej Rumunii: kłopot polega na sposobie konstrukcji narracji, która przenosi widza w centrum problemu dzięki empatycznemu, słyszalnemu głosowi dumnego z bycia Rumunem Alexa. Ukazuje przy tym prawdopodobnie jedną z najbardziej marginalizowanych i traktowanych protekcjonalnie grup etnicznych we współczesnej Europie, ale też i samą Rumunię.

Zwraca tu uwagę niemal bezpośrednia korelacja między podporządkowaniem, byciem pozbawionym głosu i brakiem kontroli w odniesieniu do konkretnej grupy oraz częstotliwością prezentowania ich zarówno w dyskursie krytycznym, jak i w sztuce - im rzadziej dana jednostka społeczna jest słyszalna (z własnej woli bądź nie), tym częściej staje się podmiotem narracji narzuconej z zewnątrz (producent i reżyser w większości przypadków stanowią nieodłączną część hegemonistycznej kultury). W dyskursie możemy określić to zjawisko mianem „nadreprezentacji”: właściwie we wszystkich filmach, obrazach czy tekstach dotyczących Europy Wschodniej można doszukać się reprezentatywnej wartości postaci Cygana - wszechobecnej z powodu liczebności tej właśnie grupy etnicznej oraz przez jej poddańczą niewidoczność. Jako kwintesencja „obcego”, na najniższym szczeblu drabiny ekonomicznej, - „Cygan” jest ucieleśnieniem tłumionych obaw i lęków „cywilizowanej" Europy, stając się tym samym wyrazistym symbolem wędrówki 
migracyjnej. W obrazie Rumuni nadchodza imigranci ukazani są jako masy ludzkie napływające do kraju, który ich nie chce i który spycha ich na margines życia społecznego - zarówno w kontekście przestrzeni, jak i dyskursu.

Początkowe sceny w zwiastunie filmu ukazują cygańskie getto na obrzeżach miasteczek Kluż czy Pata Rat, przypominających najgorsze dzielnice nędzy i slumsy w wielu krajach rozwijających się. Pierwszy odcinek zaczyna się od wyraźnych ujęć różnych grup romskich ${ }^{25}$ żyących w prowizorycznych siedliskach rozsianych po londyńskich parkach i skwerach - oko kamery pokazuje uparcie brud, smród, nędzę i ubóstwo, zapadnięte oczy czy zepsute zęby: innymi słowy, te cechy, które - jak to dosadnie ujmuje narrator (czyli Alex), zwracając się bezpośrednio do brytyjskich widzów - są w stanie wystraszyć człowieka (0.2'.26"). Ironia osoby wypowiadającej się w dokumencie zdaje się potwierdzać podejście choćby Nigela Farage stwierdzającego, że „ci cyganie” powinni zostać natychmiast odesłani do domu. W kolejnych ujęciach widzimy postać Rumuna trochę lepiej sytuowanego, ukazanego jako darmozjada na zasiłku, korzystającego ze „szczodrości” brytyjskiego państwa opiekuńczego, które wypłaca bezrobotnym rozmaite świadczenia i umoźliwia bezpłatny dostęp do służby zdrowia każdemu przybyszowi z terenów Unii Europejskiej. Takie obrazy z pewnością potwierdzają obawy Brytyjczyków i utrwalają powszechnie panujące stereotypy na temat imigrantów.

Obrazy skrajnie zubożałej, wyniszczonej, pełnej uprzedzeń Rumuni w porównaniu z Wielką Brytanią, krajem mlekiem i miodem płynącym, zadają kłam bardziej złożonym historiom ludzkiego życia zaprezentowanym później. Ujawniana w filmie ,prawda” jest jednocześnie upraszczana i staje się bardzo subiektywna za sprawą wypowiedzi osób, których historie są w ten obraz wplatane. Na przemian błyskotliwe, prześmiewcze, autoironiczne, a zarazem smutne i tragiczne opowieści stanowią nie lada wyzwanie dla widzów przyzwyczajonych do oglądania, a nie do słuchania. Co za tym idzie, często niewidoczny narrator wtrąca się np. po tym, jak zostaje pokazana radość Stefana wypłacającego z bankomatu pieniądze podatników, mówiącego coś

25 Zamiast "Rumuni” używam właśnie tego słowa z uwagi na to, że chcę wyodrębnić jedną z podgrup licznej rumuńskiej grupy etnicznej zamieszkującej tereny środkowej i południowo-wschodniej Europy. Termin 'Cygan' używany jest przeze mnie wtedy, gdy (1) chcę podkreślić pejoratywny charakter danej grupy (używam też w tym przypadku cudzysłowu); (2) gdy stanowi samookreślenie („cygańsko-rumuński”) i wreszcie (3) gdy pokrywa się to z powszechnie używanym przez ludzi określeniem odnoszącym się do określonego terenu albo do określonych grup (określenie "cygańskie getto" jest używane znacznie częściej niż "romskie getto"). 
w stylu ,zanim zaczniesz podnosić larum przeciwko zasiłkom ${ }^{26}$ przyznawanym przyjezdnym, zapamiętaj sobie jedno - imigranci zapełniają jedno na siedem miejsc pracy w Wielkiej Brytanii" (0.33'15"). Stefan być może nie jest tutaj najbardziej reprezentatywnym z imigrantów - wydaje się nie mieć szczęścia w poszukiwaniu pracy, natomiast większość migrantów z Europy Wschodniej szybko zapełnia lukę we wspominanej wcześniej gospodarce „3D”. Ale nie znaczy to, że nie próbuje szukać pracy - w istocie ukazuje się go jako gotowego i chętnego do podjęcia jakiegokolwiek zatrudnienia, aby tylko zarobić pieniądze na opłacenie córce szpitala w Rumunii (gdzie z kolei lekarze źle przeprowadzili jej operację złamanej nogi). Pod wieloma względami Stefan jest jednym z tych, którzy głosu nie mają - nieznajomość języka angielskiego sprawia, że nie może liczyć na konkretną pracę i jest zmuszony egzystować w stanie zawieszenia: nie może wrócić do domu (ponieważ rodzina uzna to za porażkę, którą obarczy właśnie jego) ani też znaleźć sobie pracy. Przykładem imigranta tego typu jest Adrian, pracownik myjni samochodowej. Pracuje cały dzień za 180 funtów tygodniowo - większość zarobionych pieniędzy wysyła rodzinie, aby uchronić dzieci przed głodowaniem. Szybkie zestawienie obrazów - z jednej strony zapyziałe miasteczko Lupeni w Rumuni (niegdyś miasto górnicze), a z drugiej - elegancka linia horyzontu rysująca się nad Burton-on-Trent, służy tylko wzmocnieniu ironii sytuacji: w Lupeni miał chociaż dach nad głową, mieszkał w otoczeniu rodziny - teraz pucuje cudze auta w tym jednym z najpiękniejszych angielskich miast, śpi na używanym materacu gdzieś pod mostem, spędzając czas w towarzystwie szczurów. Inna historia opowiada o Sandu - sentymentalnym bezzębnym - ojcu wielodzietnej rodziny mieszkającej w cygańskim getcie na obrzeżach Baia Mare w północnej Rumunii. Człowiek ten napotyka na swej drodze tę samą „barierę językową”: wyjeżdżając, by znaleźć pracę w miejscu, z którym wiązał nadzieje, wciąż naiwnie wierzy, że „Anglicy podadzą nam pomocną dłoń”, że będzie w stanie żyć wśród ludzi, którzy „będą traktować nas tu jak swoich" (12.24) - ale, rzecz jasna, skoro nie zna angielskiego - nie ma dla niego ani pracy, ani miejsca, gdzie czekano by na niego z otwartymi ramionami.

Ironia jego wypowiedzi nie moźe ujść uwadze widza - trzeba być Cyganem, żeby być zmuszonym do życia na ulicy albo wrócić do domu bez grosza przy duszy i zrezygnować z marzeń o lepszym życiu. Ludzie pokroju Stefana, Adriana czy Sandu należą do grupy, która jest wykluczana i traktowana jak obywatele drugiej kategorii, których nikt nie słucha - i to niezaleźnie 
od tego, czy w wyniku uprzedzeń i stereotypów związanych z mieszkańcami Europy Wschodniej, dzikim kapitalizmem czy też ułudą gościnnego (acz często równie bezwzględnego i pełnego uprzedzeń) Zachodu. Podczas gdy powoli przewyższają liczebnie tradycyjną brytyjską klasę średnią w wielu postindustrialnych miejscowościach, to i tak wspólnie z nimi dzielą podobny status podporządkowania. Jak zauważyło wielu komentatorów, imigrantów wschodnioeuropejskich przedstawia się podobnie jak mało zamożne białe klasy robotnicze, składające się na margines społeczny (zob. Veličkovićc ${ }^{27}$ ): ubierają się biednie, ich gusta są niezbyt wysublimowane, styl mówienia grubiański, a maniery dalekie od cywilizowanych. Niski status społeczny odbija się na ich twarzach - ludzie tacy prawie zawsze wyraźnie artykułują swoje lęki przed „chmarą” imigrantów (którzy z kolei rywalizują z nimi w wyścigu o pracę czy inne zasoby). To podobieństwo zostaje w pełni wykorzystane w filmie fabularnym Kena Loacha Wolny świat, który z powodzeniem balansuje na granicy fikcji i dokumentu fabularyzowanego.

Jak wielu polskich robotników, którzy pojawili się w filmie Tima Samuelsa Polacy nadchodza - Karol, bohater tego obrazu - jest pracowitym, uczciwym człowiekiem, ukazanym w korzystnym świetle. Cechują go również inteligencja, wrażliwość i empatia, której wyraźnie brakuje wspominanej wcześniej Angie - samotnej matce, przedstawicielce brytyjskiej klasy średniej, zajmującej się rekrutowaniem imigrantów do pracy. I choć Karol to wzór wszelkich cnót, jego postać ukazana jest tutaj zbyt jednostronnie, co z kolei definiuje postawę i działanie Angie. Rostek i Uffelmann postrzegają Karola jako osobę, której cechy zostały określone juź na samym początku, zdefiniowane przez rodzaj przesłania, jakie reżyser chce przekazać widzom. Krytykują oni film dokładnie z tego powodu: zarówno Karola, jak i innych ciężko pracujących imigrantów, w których imieniu zdaje się wypowiadać - nikt nie słyszy. I rzeczywiście: choć wypowiedzi Karola są mocno w niniejszym filmie akcentowane, właściwie przechodzą bez echa. Podczas gdy mężczyzna wyraża swoje niezadowolenie ze sposobu, w jaki zarówno on, jak i 49 innych polskich imigrantów zwerbowanych do pracy na Wyspach zostało potraktowanych przez agencję Angie - czy nawet w trakcie bezpośredniej konfrontacji z samą zainteresowaną (kiedy wytyka jej nadużycia, jakich dopuściła się za

27 V. Veličković Balkanisms Old and New: The Discourse of Balkanism and Self-Othering in Vesna Goldsworthy's Chernobyl Strawberries and Inventing Ruritania, w: Facing the East in the West: Images of Eastern Europe in British Literature, Film and Culture, eds B. Kor te, E.U. Pirker, S. Helff, Rodopi, Amsterdam-New York 2010, S. 198. 
pośrednictwem własnej agencji w stosunku do imigrantów), ona zaledwie przeprasza i chwilowo go „ułagadza”, idąc z nim do łóżka. Wypowiedzi Karola nie przekładają się na konkretne działania, na nic się nie uskarźa i w zasadzie nie wpływa na działanie systemu opartego na powielaniu tego typu zachowań i stosowaniu różnych nadużyć wobec ludzi, którym - w przeciwieństwie do Karola - brak asertywności czy płynności w posługiwaniu się językiem angielskim.

Nawet jego końcowa decyzja o powrocie do Polski, która zdaje się potwierdzać wyższość więzi i przywiązania emocjonalnego nad interesem ekonomicznym, moźe być odczytana z perspektywy określonego porządku ideologicznego, zaprezentowanego $\mathrm{w}$ filmie, a zdominowanego przez punkt widzenia lewico-liberalnego intelektualisty z Zachodu, który mimo możliwości wyrażenia swojego niezadowolenia i tak pozbawiony jest prawa głosu (zob. Rostek i Uffelmann ${ }^{28}$ ). Czuje się kimś obcym czy wręcz wykluczonym ze społeczności brytyjskiej i nie chce dłużej być traktowany jak popychadło. Choć widzowie mogą być pełni podziwu dla jego godnej i szlachetnej decyzji o wyjeździe, Karol posługuje się jednak językiem typowym dla wielu innych imigrantów, których fatalne położenie ekonomiczne zmusiło do rezygnacji z komfortu emocjonalnego w imię ekonomicznego bezpieczeństwa, , jakie zapewniają im ich „gówniane zajęcia”. Karol - w przeciwieństwie do wielu innych imigrantów - potrafi dobrze mówić po angielsku (tłumaczy nawet za innych oraz w ich imieniu, wchodząc w rolę mediatora i - co najbardziej istotne - odmawia przyjmowania pieniędzy za tego typu „usługi”). Podaje przy tym w wątpliwość swoją „reprezentatywność” na tle masy imigrantów pozbawionych wszelkich praw obywatelskich.

Rostek i Uffelmann zauważają, że Karol „nie akcentuje tak wyraźnie pozycji Polaka-imigranta, ale pozycję angielskiego pracodawcy: [...] pełni funkcję szablonowego stróża moralności i obrońcy idealistycznych wartości. Głos polskiego imigranta jest zagłuszany przez angielskiego reżysera, który już wcześniej narzucił swoją definicję porządku społecznego"29. Niemniej jednak argument, którym posługują się krytycy, zdaje się wypaczony przez ich własną wizję porządku w Wielkiej Brytanii. Przez to, że - ich zdaniem - postać Karola jest odzwierciedleniem antykapitalistycznego bełkotu reżysera znanego ze swojego lewicowego podejścia, sami dorabiają pozatekstową ideologię do oczekiwanej od niego „reprezentacyjności”, o której pisałam

28 J. Rostek, D. Uffelmann Can the Polish Migrant Speak?...

29 Tamże, s. 313-314. 
wcześniej - powinien bowiem być symbolicznym uosobieniem jednostki, którą możemy określić mianem „wyzyskiwanego polskiego (bądź wschodnioeuropejskiego) imigranta". Moim zdaniem dzieje się tak dlatego, że dopuszczono go do głosu - to właśnie odróżnia Karola od mu podobnych i przełamuje stereotypy: w osobie Karola dostrzegamy nie tylko imigranta ekonomicznego, nie tylko Polaka, nie tylko mieszkańca Europy Wschodniej, ale - co najwaźniejsze - istotę ludzką, która postanawia wznieść się ponad określone wcześniej czynniki ekonomiczne, a te z kolei wydają się narzucać motywy działania pozostałym bohaterom filmu.

Omawiany film wystrzega się jednak moralnych osądów na różne sposoby, proponując w zamian bardziej obiektywną ocenę budzących wątpliwości sytuacji. Kwestie drugorzędności/poddaństwa komplikują się z powodu marginalnego i niedającego żadnych uprawnień statusu głównych bohaterów w brytyjskim społeczeństwie: Angie wywodzi się z klasy robotniczej (wyraźnie zdradza ją sposób mówienia), jest samotną matką i ma więcej długów niż włosów na głowie - sytuacja ta ma wyraźnie negatywny wpływ na jej syna Jamiego, który z kolei przejawia skłonność do wdawania się w bójki czy też terroryzowania rówieśników w szkole. Nietrudno sobie wyobrazić, jakie zmiany musiały zajść w jej postępowaniu, że bez mrugnięcia okiem wdaje się w szemrane interesy. Takie zachowanie jest bezpośrednim następstwem trudnej sytuacji życiowej, w jakiej sama się znalazła. Wybory, jakich dokonuje, są jasno określone, a motywów jej bezwzględnego zachowania można upatrywać w trosce o syna. Być może nie jest doskonała i w pewien sposób naiwna, ale z pewnością w filmie jest kimś więcej niż tylko postacią nacechowaną ideologicznie. Chwilami da się wyczuć, że nie przychodzi jej z łatwością nieustanne rozstawianie imigrantów po kątach (co sama przed sobą tłumaczy jako wyższą konieczność i jedyną moźliwość egzystencji w świecie, w którym człowiek człowiekowi wilkiem). Zdarzają się przypadki, kiedy Angie okazuje jednak odrobinę empatii, jak choćby wtedy, gdy wspiera irańskiego uchodźcę desperacko poszukującego pracy. Poza tymi nielicznymi scenami film jest przewidywalny - to właśnie Angie pełni funkcję tego „białego wyzyskiwacza” (mimo że kobiety pochodzące z klasy robotniczej raczej nie parają się tego typu pracą po nocach), natomiast Rose (jej koleżanka ze zmiany, którą widz powinien postrzegać jako jeszcze bardziej podporządkowaną ze względu na kolor skóry) decyduje się wycofać, gdy Angie wydaje policji imigrantów przewożonych nielegalnie w przyczepie kempingowej. W przypadku Rose jej „podporządkowanie rasowe” sprawia, że znajduje w sobie więlssze pokłady empatii w zderzeniu ze współczesną formą 
niewolnictwa. Jej postawa moralna - niczym u Karola - jest zdecydowanie lepsza niż u Angie, mimo podobieństw związanych z ich niskim statusem społecznym.

To właśnie w takich odcinkach głos reżysera wyraźnie odbija się w postaciach, które pokazuje. Odcinek, w którym banda rozwścieczonych imigranckich frustratów porywa syna Angie, aby później zapytać, czy w jej mniemaniu to właśnie jej syn jest wart więcej niż ich dzieci, wyraźnie krytykuje taki porządek rzeczy. Ukazanie ich jako ludzi nieszkodliwych i odznaczających się moralnością w konfrontacji z bezwzględną w swej postawie Angie jest czysto ideologiczne i w całości wypełnia przestrzeń „moralnej supremacji” opisywanej przez Van Heuckeloma ${ }^{30}$ czy Rostek i Uffelmanna - brakim wiarygodności w tym, jak się zachowują, jak i o czym mówią.

Ten konkretny odcinek drąży dalej kwestię pozbawienia głosu i zrozumienia. Podczas „akcji” z uprowadzeniem porywacze używają bliżej niezidentyfikowanego wschodnioeuropejskiego języka, który w wersji DVD figuruje jako „napisy polskie”. Jednakże w istocie jest to język południowosłowiański, być może nawet serbsko-chorwacki ${ }^{31}$. Nie zmienia to jednak faktu, że dla anglojęzycznego widza wszystko to sprowadza się do niezrozumiałego bełkotu (wątpię, aby wielu Anglików wyłapało różnice między językiem polskim używanym w filmie a innym podobnie brzmiącym językiem wschodnioeuropejskim). Aby go zrozumieć, należy najpierw tę dziwaczną mowę przetłumaczyć. Obraz stawia ponadto pytanie, kto jest docelowym odbiorcą tego typu filmów. To jednak nie ma większego znaczenia - ze wszystkich wspominanych wcześniej filmów Wolny świat odbił się najsłabszym echem - w kinach wyświetlano go tylko przez jeden dzień, niedługo później trafił do dystrybucji w formacie DVD. Czy moźna zakładać, że poraźka tego obrazu związana była z jego tematem? Niewielu interesuje to, co do powiedzenia mają imigranci - o ile ich wypowiedzi nie zostaną uprzednio 'przetłumaczone' i odpowiednio 'zinterpretowane' przez najbardziej opiniotwórcze media, tak aby przypodobać się panującym nastrojom społecznym - w dalszej części artykułu pokażę, jak można przenieść taką strategię na grunt reportażu na przykładzie

K. Van Heuckelom Polish (Im) Potence:Shifting Representations of Polish LabourMigration in Contemporary European Cinema, w: Contemporary Polish Migrant Culture in Germany, Ireland, and the UK, eds J. Rostek, D. Uffelmann, Peter Lang, Frankfurt am Main 2011, s. 277-298. rządkowania społecznego nawet niżej niż Polacy będący bądź co bądź obywatelami Unii Europejskiej. 
emitowanego w kanale Channel 4 serialu Rumuni nadchodza, będącego idealną ilustracją tego zjawiska.

Siła filmu Kena Loacha polega m.in. na tym, że podkreśla on niezwykle istotną rolę głosu i artykulacji niezbędnej przy prezentacji imigrantów - głos nie tylko rozumiany w kategoriach osoby mówiącej czy słuchającej, ale także ze względu na dostrzegalne różnice, jakie ze sobą niesie. Jak powszechnie wiadomo, w Wielkiej Brytanii „akcent" to nie tylko cecha demaskująca pochodzenie czy teź przynależność etniczną, ale także znak przynależności do klasy społecznej czy wykształcenia. Oto jeden z powodów, dla których imigranci z Europy Wschodniej są postrzegani inaczej niż tzw. biały lumpenproletariat, na który składają się głównie pozbawieni chęci do pracy młodzi mężczyźni. W przeciwieństwie do nich imigranci są praktycznie zawsze przedstawiani jako niezwykle pracowita, sumienna i niewzbudzająca krytyki grupa. Nie bez znaczenia jest też to, że należą do tej samej - od lat spychanej na margines grupy społecznej. Choć są biali, to ich łamana angielszczyzna i ciężki akcent sprawiają, że przez szanowanych, wykształconych i potrafiących pięknie się wysławiać Brytyjczyków, reprezentujących klasę średnią, są postrzegani jak odszczepieńcy i swoim grubiaństwem wprawiają w zakłopotanie tych, którzy reprezentują wyższy poziom. Wspominany podział nie dotyczy tylko ogólnej relacji Brytyjczycy - imigranci, ale raczej przepaści klasowej. Ten sam rodzaj dyskomfortu, jaki odczuwają przedstawiciele brytyjskiej klasy średniej, gdy przypadkowo natkną się na młodocianych „dresiarzy” (najpewniej będących na zasiłkach, zaopatrzeni w tanie piwo i niegarnący się do pracy j32), da się również zauważyć w przypadku tworzących klasę średnią wykształconych imigrantów z krajów Europy Środkowej względem swoich rodaków ${ }^{33}$ - „oni” nie są jak „my” (cywilizowani, czyści czy wykształceni). To „my” jesteśmy bardziej jak „wy” (brytyjska klasa średnia), a nie jak „oni” - co z tego, że w paszporcie mamy wpisany ten sam kraj pochodzenia.

Powyższe rozważania w zasadzie wyjaśniają oburzenie i ożywione reakcje, z jakimi spotkał się dokument Rumuni nadchodzą, zarówno w samej Rumunii, jak i wśród rumuńskiej społeczności imigranckiej w Wielkiej Brytanii. Swoisty bunt okazał się żałosny w swym wydźwięku, a reprezentujący głos

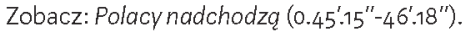

Nawet wśród "swoich" panuje pewna hierarchia. Badacze z krajów wschodnioeuropejskich, którym dobrze powodzi się na emigracji, szanują - i często korzystają z usług - sobie podobnych rodaków. Zachowują się tak jednak tylko do pewnego momentu, czyli dopóki nie są zmuszeni obcować z ich własną "kulturą” i zwyczajami. 
rumuńskiej społeczności Stefan czy Sandu zdają się tylko potwierdzać jego bezcelowość, będącą wypadkową braku pewności siebie, obaw związanych z odnalezieniem się w obcej kulturze czy niedostosowania do otoczenia mających swe uwarunkowania historyczne. Niektóre obrazy miejsc przewijają się przez cały film, ukazując opuszczone, zniszczone czy wręcz postapokaliptyczne przestrzenie przypominające wysypiska śmieci, przez które przedzierają się mali chłopcy w poszukiwaniu złomu. A za pożywienie wystarcza im zaciąganie się farbą schodzącą z torebek. Obraz ten ukazuje olbrzymi kontrast społeczny w samej Rumunii - z jednej strony buszujące wśród odpadków dzieci, a nieopodal nowo wybudowane ogromne centra handlowe cieszące się popularnością wśród nowobogackich dzieciaków wywodzących się z niedawno powstałej klasy średniej, szpanujących drogimi komórkami czy zapełniających tłumnie bary szybkiej obsługi. Choć obydwie grupy reprezentują mieszkańców Rumunii, to jednak do tych pierwszych nikt nie chce się przyznawać - tacy jak Alex, Stefan czy Sandu wręcz desperacko pragną uciec nie tylko ze względu na ogrom biedy, ale głównie dlatego, że bywalcom nowoczesnych błyszczących przybytków (od jakich zaroiło się w postkomunistycznej Rumunii) tacy ludzie nie są do niczego potrzebni: praktycznie nie istnieją, zarówno w sferze społeczno-kulturowej, jak i politycznej.

Rzecz jasna, niewielu też chce ich widzieć „u siebie”, w Wielkiej Brytanii. Chyba że przyjeżdżają jako opiekunowie osób starszych do domów starców, których tutaj nie brak a które borykają się z brakiem wystarczającej liczby pracowników $w^{34}$. Odcinek drugi - zamiast na polifonii - opiera się bardziej na ukazaniu wizualnego kontrastu między tym, jak prezentuje się dom opieki Grange Sands i jego otoczenie na pięknych zdjęciach zamieszczonych na stronie internetowej, a jak wygląda w rzeczywistości to szare, smutne i kompletnie nieciekawe miasteczko Sheffield w północnej części Anglii, do którego wreszcie przyjeżdża przejęta Mihaela, pielęgniarka z Rumunii. Kontrast ten dotyczy zresztą całego kraju. W wyobraźni większości ludzi to głównie bujna roślinność zielonych parków, Beatlesi, domy przypominające pałace - zamieszkiwane przez miłych, uśmiechniętych i szczęśliwych ludzi. Rzeczywistość, z jaką przychodzi im się tam zmierzyć, wygląda jednak zupełnie inaczej: nie ma pałaców - są za to małe, szarobure domki. Ludzie, których twarze

34 Celną uwagę Mihaeli warto zacytować w całości: „Tam skąd ja pochodzę, nikomu nawet przez myśl by nie przeszło, żeby wysyłać matkę lub ojca gdzieś daleko po to tylko, aby opiekowali się nimi obcy ludzie... Ale może ma to sens, gdy cierpisz na nadmiar gotówki, a niedobór wolnego czasu" $\left(23^{\prime} 05^{\prime \prime}\right)$. 
nie wyrażają większych emocji, są po prostu zmęczeni życiem. Nakładane na siebie obrazy mówią wszystko: malutkie mieszkanko na obrzeżach Sheffield i dom rodzinny, który opuściła; wielka oświetlona i dobrze utrzymana posesja, z ogrodem porośniętym winoroślą, a przede wszystkim ze wspaniałą rodzinną i sąsiedzką atmosferą; pielęgniarka wraz z mężem, matką i córką - ciepła, sympatyczna, być może trochę próżna, troszeczkę naiwna, ale pełna optymizmu i empatii - dla kontrastu reakcje malujące się na twarzach Brytyjczyków pytanych o zdanie na temat imigrantów, będących niemalże Brytyjskimi odpowiednikami zmęczonych, niewykształconych rumuńskich Cyganów, których mogliśmy zobaczyć na początku filmu. Podobne - trafne zresztą - zestawienie pojawia się w Wielkiej rumuńskiej inwazji, gdzie z kolei postać skromnie ubranego, acz poczciwie wyglądającego taksówkarza rumuńskiego ${ }^{35}$ w średnim wieku wyraźnie kontrastuje z chuligańskimi wybrykami pijanej młodzieży brytyjskiej. Jedno zdanie: „To nie jest normalne”, podsumowuje to, co ten mężczyzna - mówiący słabo po angielsku - ma na ten temat do powiedzenia przed kamerą. Zdaje się to potwierdzać wyobrażenia wielu Europejczyków ze wschodu na temat jakże wyszukanej kultury brytyjskiej, jakby z powieści Jane Austen. Na miejscu okazuje się jednak, że nijak ma się ono np. do dość luźno pojmowanej przez Brytyjczyków kultury picia.

Czas wrócić do wciąż zmieniającej się formy pytania postawionego przez Spivak: „Czy podporządkowani potrafią mówić, i zobaczyć, w jakim stopniu odnoszą się do reportaży takich jak Rumuni nadchodzą. Spivak zakłada, ze podporząd kowani nie mają prawa głosu, a w ich imieniu zawsze wypowiada się ktoś inny ${ }^{36}$. Co więcej, nawet jeśli już uda im się dojść do głosu, to dyskurs ten nie idzie w parze z założeniami czysto imperialistycznej kultury. Na wiele sposobów obrazuje znane przysłowie, ,i tak źle, i tak niedobrze” - jakkolwiek by na to spojrzeć, zawsze znajdą się ci, których głosu nikt nie usłyszy, oraz historie, które nie zostaną opowiedziane. Z jednej strony obraz imigranta pokazany w filmie zdaje się potwierdzać (a nawet wzmacniać) stereotypowe

35 Człowiek ten jest jednym z wielu rumuńskich imigrantów ściągniętym do pracy przez brytyjskie biuro pośrednictwa pracy w celu zapełnienia luk na stanowiskach taksówkarzy w mniej znaczących angielskich mieścinach; w Bukareszcie ukończył wstępne szkolenie w tym zakresie, a następnie przyjechał do Maidstone, małej mieściny w hrabstwie Kent, za namową swojej żony, zakochanej w powieściach Jane Austin. 
postrzeganie rumuńskiego imigranta ${ }^{37}$ (często połączone z wyobrażeniami na temat Romów); z drugiej zaś dopuszczając do głosu niektóre z bardziej zepchniętych na margines społeczności (zarówno pod względem pochodzenia etnicznego, jak i przynależności do określonej klasy społecznej) i umożliwiając ich historiom dotarcie do szerszego grona odbiorców, film nie tylko obnażył „wrażliwość” Rumunów, ale także pokazał, jaki jest stosunek osób z zewnątrz do kultury brytyjskiej. Najlepszym przykładem jest tutaj Alex, kanadyjsko-rumuński imigrant - niegdyś przedstawiciel klasy średniej, dziś bezdomny - który przez cały film próbuje wywracać wartości bliskie zarówno brytyjskiej, jak i rumuńskiej kulturze. Przepełnia go nieopisana radość, kiedy pokazuje widzom, w jaki sposób udaje mu się wraz ze kumplami tworzyć prowizoryczne legowiska na londyńskich parkingach, pod komisariatem policji. Alex odznacza się niebudzącą żadnych wątpliwości inteligencją, a mimo to przyszło mu żyć w złych warunkach. Takie sytuacje nie należą do rzadkości i jest to w pewnym sensie porażka państwa opiekuńczego, które zakłada np. że skoro jest się bezdomnym, to nie ma się stałego adresu zameldowania i w związku z tym nie można ubiegać się o pracę. Jeśli zaś nie moźna dostać pracy, to nigdy nie będzie się w stanie kupić mieszkania - nawet najciaśniejszego i najbardziej zapuszczonego. Mimo to, patrząc na Aleksa, widz zanadto nie lituje się nad jego losem. Dzieje się tak z dwóch powodów: po pierwsze, sam zainteresowany wydaje się przyjmować wszelkie ciosy z godnością. Drugiego powodu upatrywać można w tym, że jego głos jest na tyle silny, że przykuwa uwagę i podnosi kwestie istotne nie tylko dla imigrantów, ale także te nurtujące przeciętnego widza, np.: czy będąc pracowitym i przykładnym obywatelem mam szansę awansować w hierarchii społecznej; czy rząd brytyjski faktycznie rozdaje zasiłki każdemu, kto tylko przyjedzie do kraju jak imigrant?

Komentarz zamieszczony na forum przez jednego z rumuńskich widzów dokładnie wyjaśnia taką właśnie dwuznaczność w odbiorze prezentowanych treści: „lako Rumun mieszkający w Londynie miałem nieodparte wrażenie, że pierwszy odcinek ogólnie oparty był na tanich chwytach, ale przekaz płynął prosto z serca. Razem ze mną film oglądał George, mój angielski znajomy, który - jakkolwiek dziwnie to może zabrzmieć - powiedział, że w pewnym sensie solidaryzuje się jego głównym bohaterem, Sandu [...]. George doskonalezdaje sobie sprawę, że nie wszyscy Rumuni są tacy jak Sandu, ale stwierdził też następującą rzecz: «Gdybym oglądał te produkcję jako osoba, która nigdy w życiu nie miała do czynienia z rumuńskimi imigrantami, myślałbym, że Rumunia to taki kraj-getto, gdzie wszyscy żyją upchnięci obok siebie jak sardynki w puszcze - na kupie w jednym pokojus". Zob. http://www.vice.com/read/the-romaniansare-coming-documentary-channel-4-protest- 876 . 
Pod wieloma innymi względami dokument ten wyraźnie przemawia do widza - wybór najbardziej „reprezentatywnych” członków społeczności imigranckiej oraz metaforyka ich narracji składają się na ogólną wizję dys kursu. Zgodnie z jego zasadami Europa Wschodnia to czarna dziura, gdzie zatrzymał się czas, miejsce uosabiające chaos, postkomunistyczne zgliszcza i zacofanie. Taki punkt widzenia przyjmuje wielu - nawet bardzo ambitnych w swej twórczości - dokumentalistów, jak na przykład Tim Samuels w dwóch wyprodukowanych dla BBC obrazach, począwszy od rozmów z - wydawałoby się - ludźmi wyważonymi, prezentującymi na ogół liberalne poglądy. Jako przykład podaje kompletny brak poszanowania zasad obowiązujących innych obywateli, w tym tych dotyczących składowania odpadów bądź utrzymywania porządku w zamieszkiwanej okolicy (Polacy nadchodza). Kolejnym przykładem podobnego podejścia do imigrantów może być typowy przedstawiciel angielskiej klasy średniej - handlujący samochodami mężczyzna, którego wręcz odrzucają hordy Cyganów snujących się po mieście. Posądza ich o to, że odstraszają mu klientów ze względu na odór, jaki wydzielają dookoła. Jak sam mówi: „robią tylko mnóstwo hałasu i smrodu dookoła” (Wielka rumuńska inwazja). Oczywiste jest więc, że ukazanie imigrantów w kontekście brudu, smrodu, nędzy i ubóstwa - potęgujące przy tym wszelkie uprzedzenia i utwierdzające ludzi w opiniach na temat przyjezdnych z terenów Europy Wschodniej - stanowi lepszy materiał na serial telewizyjny emitowany w porze największej oglądalności niż historia ludzi inteligentnych i obytych, których sytuacja zmusiła do opuszczenia Europy Wschodniej i do stania się siłą napędową brytyjskiej gospodarki. Jednym z najbardziej trafnych komentarzy odnośnie do tych obrazów, na jakie się natknęłam, jest wypowiedź pewnej Kubanki. Stanowi podsumowanie filmów nastawionych na zyski, goniących za sensacją i zwyczajnie kłamliwych pseudodokumentalnych produkcji. Pozwolę sobie zacytować ją w całości:

Tak samo jest z filmami dokumentalnymi dotyczącymi Kuby - nieważne czy realizacją zajmuje się BBC, czy zwykli Kubańczycy, którzy chcą rozesłać swój materiał w świat. W obydwu przypadkach chodzi o sprzedaż, a pospolitość się nie sprzedaje - tylko ekstrema. Splądrowane ulice, zapadające się domy, ludzie robiący wokół siebie zamieszanie (choć nieco krzykliwi i przesadnie gościnni), brud, prostytucja, oddziaływanie na zmysły, dziecięca radość, brak kontroli nad narodzinami - słowem wszystko to, czego potrzeba aby zrobić dobre show. To, że narratorem w tym dokumencie był Rumun, sprawia, że całość staje się jeszcze większą 
żenadą pozbawioną obiektywności. Po pierwsze, rumuńskiemu uchodźcy producenci zapłacili. Po drugie ludzie wywodzący się z biednych krajów zazwyczaj są bardzo krytyczni zarówno w stosunku do siebie samych, jak i do miejsca pochodzenia. I wreszcie po trzecie - doskonale zdają sobie sprawę, że ich ubóstwo stanowi idealny materiał na film i dlatego ochoczo przystają na utrwalanie stereotypów i pozwalają zagłaskać się na śmierć przez „nadrzędną" kulturę kręcenia filmów dokumentalnych.

Aspekt komercyjny jest tutaj ewidentny i łatwy do wychwycenia. Pogoń za sensacją przejawia się za pośrednictwem dystansu między widzem a bohaterami. Współczesne medium filmowe - które do perfekcji opanowało technikę "ruchomych obrazów” - stosuje także wiele mechanizmów charakterystycznych dla fotografii filmowej, którą cechują natychmiastowość i realizm ukazywanych materiałów. Istotną rolę odgrywa tutaj również styl kadrowania (czasami motywowany politycznie): w takim samym stopniu jak fotografia, film może mieć (i często ma) wartość etyczną (jak choćby Shoah z 1985 roku, In the Year of the Pig [Rok świni] z 1968 roku, The Battle of Chile [Bitwa o Chile]" z lat 1975-1979, a nawet The Corporation [Korporacja] z roku 2003). Chociaź wydaje się, że obrazy są bezpośrednie i dzięki temu bardziej przejrzyste (z założenia mają oddawać prawdę), to mogą stać się też narzędziem manipulacji zdecydowanie bardziej skutecznym niż zapis tekstowy. Jako medium ilustrujące rzeczywistość film może ją również dowolnie przeinaczać albo też oddawać ją tylko częściowo za sprawą uszczegółowienia niektórych elementów, ich nieuchwytności czy braku wiarygodności. Lecz tam, gdzie narracja zazwyczaj zbacza nieco z kursu, ruchomy obraz (podobnie jak fotografia filmowa) udaje odwzorowywanie rzeczywistości, pokazując ją rzekomo taką, jaka jest naprawdę. Nawet pod płaszczykiem artyzmu w filmie nie ma miejsca na przypadek. Wszystko podlega tu kontroli: przestrzeń, punkt widzenia, ruch i koloryt. To prowadzi do swoistego konfliktu interesów między uchwyceniem obserwowanej rzeczywistości a konwencją filmową kodującą tę rzeczywistość na swój sposób. Dodatkowo dziennikarski punkt widzenia, będący nieodłączną częścią reportażu dokumentalnego, również wpływa na pojawianie się niejasności czy dwuznaczności, których z kolei właściwie nie da się uniknąć, mając do czynienia z tym konkretnym medium.

Podsumowując, sylwetka wschodnioeuropejskiego imigranta zaprezentowana w omawianych filmach pod wieloma względami budzi nie mniejsze kontrowersje i jest odbierana niemalże tak samo dwuznacznie, jak w przypadku publikacji drukowanych bądź internetowych. Niemniej jednak historie 
opowiadane przez bohaterów tych filmów - często na przekór konwencji filmowej czy wbrew intencjom reżyserów - „zwyciężają", zyskując drugie dno i ukazując, jak bardzo złożonym zagadnieniem jest zjawisko imigracji (co większość środków masowego przekazu pomija). Historie opowiadane przez zwykłych ludzi - choć czasem nieco podkoloryzowane - są wciągające i dają bardziej szczegółowy obraz rzeczywistości niż w przypadku dyskursu medialnego powielającego często tendencyjne opinie bądź krzywdzące stereotypy, z którymi muszą mierzyć się imigranci z Europy Wschodniej. Chociaż znów przypomina o sobie problem 'reprezentacyjności', omawiane wyżej filmy mają tę zaletę, że przyczyniają się do uświadamiania większemu gronu odbiorców, z jakimi problemami przychodzi zmagać się najbardziej marginalizowanym grupom imigranckim. To, że społeczeństwo ich nie dostrzega, często idzie w parze zarówno z wykluczeniem politycznym, jak i kulturowym. Twórcy tych obrazów wyraźnie zaznaczają, że nie wszystkie działania imigrantów są z natury pozytywne bądź też pożądane - w związku z tym pokazują różne ewentualne korzyści, a także zagrożenia płynące z globalnej mobilności. Jak w przypadku obrotu towarów i usług, tak samo przepływ osób pokazany jest z perspektywy nastawionego na tanią siłę roboczą i jak największe zyski globalnego rynku. Filmy takie muszą wypowiadać się za wszystkich i w imieniu wszystkich, a juz szczególnie w imieniu imigrantów ze środkowej Europy (niezbyt dobrze radzących sobie na rynku pracy czy próbujących odnaleźć się w społeczeństwie z marnym skutkiem). Czasami mogą też okazać się pozbawione obiektywizmu, kreślić obraz imigrantów odpowiadający powszechnie panującym nastrojom, potęgować uprzedzenia i utrwalać dobrze znane juź stereotypy na temat imigrantów. Jednocześnie jednak zmuszają widzów - czy to większość Brytyjczyków, czy teź należących do najliczniejszych społeczności imigranckich Polaków bądź Rumunów - do zrewidowania poglądów na temat imigrantów i zastanowienia się, czyj głos jest bardziej potrzebny. I choć w zasadzie nie mamy nic przeciwko międzynarodowej wymianie produktów, usług czy kapitału - to zaczynamy być podejrzliwi w przypadku przepływu ludności. „My” zarówno jako mieszkańcy Europy Zachodniej, czyli tzw. „krajów goszczących” i - paradoksalnie - wschodnioeuropejskie społeczności imigranckie. Nie przeszkadza nam specjalnie kupowanie i używanie nowoczesnych gadżetów wyprodukowanych przez tanią siłę roboczą gdzieś w krajach Trzeciego Świata. Gdy natomiast zachwycamy się najnowszym majestatycznym wieżowcem wzniesionym gdzieś w centrum Londynu, nie chcemy oglądać twarzy tych, którzy w pocie czoła pracowali nad tym, żeby powstał. Boimy się bowiem konfrontacji z brutalną prawdą i niegodziwością, 
z jaką traktowani są wszyscy ci, którzy pośrednio pracują na to, abyśmy mogli korzystać z dobrobytu tego świata. I jeżeli dzięki danemu filmowi choćby na chwilę opuszczamy naszą strefę przeświadczeń - wtedy jak najbardziej zasługuje on na uwagę.

Przełożyła Aleksandra Matysiak

\section{Abstract}

\section{Cristina Şandru}

INDEPENDENT SCHOLAR

Watching the New'Subaltern' in Britain: East-Central European Migrants and Their Filmic Avatars

Post-Cold-War global events have pushed the hitherto shadowy figure of the migrant centre-stage: she has become the embodiment of a contrasting ideological landscape in which unprecedented levels of mobility wage daily battle with renewed anxieties about the'stranger within' and the invading 'Other' from outside. In a post-1989 European context, this mobility has translated into successive waves of immigration from EastCentral Europe to the West, which have shaped debates on integration, human rights, citizenship, cultural diversity and national identity. The article looks at contemporary cinematic and television productions that problematize the impact of this phenomenon in Britain, with particular focus on Channel 4's three-part series The Romanians Are Coming (2015) and Ken Loach's hybrid docu-drama It's a Free World, 2007.

\section{Keywords}

migrant, immigration, East-Central Europe, Poland, Romania, film 